\title{
Linguistic Diversity in the English-Medium Instruction Classroom in Nepal: Challenge or Chance
}

\author{
Mohan Singh Saud \\ Kailali Multiple Campus, Dhangadhi \\ Tribhuvan University, Nepal \\ E-mail: mssaud35@gmail.com
}

Received: May 15, 2019 Accepted: May 31, 2019 Published: June 4, 2019

doi:10.5296/ijele.v7i1.14887 URL: https://doi.org/10.5296/ijele.v7i1.14887

\begin{abstract}
Linguistic diversity is a common phenomenon in urban Nepalese societies. However, Nepalese educational system has not adapted this reality very well. Therefore, considering the linguistic landscape of the multilingual city in Kathmandu, this study focuses on the linguistic and cultural diversity in multilingual school space of public education system. The purpose of this study was to explore how the English language teachers address the issue of students' linguistic diversity in English as a medium of instruction (EMI) language policy classrooms, whether they take this as a challenge of teaching or chance for learning. Employing a phenomenological design of qualitative research, three English language teachers were interviewed to collect information for this study. Their audio recorded interviews were transcribed, coded and then analyzed and interpreted using a thematic approach linking with relevant theories. The findings indicate that linguistic diversity in the English classrooms can be a valuable resource for learning and developing effective intercultural competence in the learners to cope with culturally diverse social contexts. Though linguistic diversity has become a challenge of teaching for English language teachers, it can be changed into an opportunity for learning through intercultural awareness. EMI language policy of public schools has become a barrier to change multilingualism as a resource for learning.
\end{abstract}

Keywords: Linguistic diversity, multilingualism, linguistic landscape, English as a medium of instruction, monolingual bias 


\section{Introduction}

Being a multiracial country with varying geographical landscape, linguistic and cultural diversity is a common phenomenon in Nepal. The 2011 population census has recorded 123 languages spoken as mother tongue. Due to migration and urbanization, linguistic diversity in the English classrooms has been being the growing social issue in the context of Nepal. Multilingualism is a common phenomenon in present day society; there are almost no territories in which only one language is used by the certain group of people. No language is bound in a certain territory due to migration and globalization. As a result, linguistic diversity has become a common phenomenon in the English classrooms today. Linguistic diversity is a reality in the English language classroom, particularly in the contexts of Nepal, where the learners come from diverse linguistic, cultural, geographical, economic, and social backgrounds. In this scenario, my interest is to see how English language teachers address the issue of students' linguistic diversity in their English as a medium of instruction (EMI) classrooms, whether they take it as a challenge of teaching or chance for learning.

Students come from homes where a language other than English is spoken. These students are often referred to as English language learners. Across the nation, as more than 123 languages and language varieties are spoken in our schools, with Nepali being the most predominant, teachers need to be adequately prepared to work with these students in the English classrooms. However, in today's society, nobody can be purely monolingual as even the ethic children can speak at least their mother tongue as well as Nepali as their second language. They learn English as a foreign language (Shrestha, 1983; Shrestha, 2008; Bista, 2011), now commonly referred to as English as an international language (McKay, 2002, 2012). So, every ethnic student learning English becomes at least "trilingual" (Gogolin \& Duarte, 2017), knowing their mother tongue, Nepali and English to some extent.

Diversity of languages and cultures is growing throughout the country in today's society. In the school contexts, diversity can give students an opportunity to interact with one another in the classroom regardless of ethnicity, culture, religion, or creed thereby developing intercultural competence. Intercultural competence refers to people's "ability to interact in their own language with the people from another country and culture" (Byram, 1997). With increased globalization, migration and immigration, there has been a growing recognition for the need for an intercultural focus in language education (Moeller \& Nugent, 2014).

As culture is the marginalized sister of language (Hennebry, 2014), it is necessary to develop intercultural awareness in the students. Linguistic diversity and cultural diversity go side by side. Intercultural communicative competence (ICC) takes into account language teaching and focuses on "the ability to interact with people from another country and culture in a foreign language" (Byram, 1997). In Byram's view, a person who has developed ICC communicates effectively, taking into consideration their own and the other person's viewpoint and needs; mediates interactions between people of different backgrounds, and strives to continue developing communicative skills (López-Rocha, 2016). The professional standards in the field of foreign language pedagogy focus on communication, cultures, connections, comparisons, and communities (Lear \& Abbott, 2008), designed as the 5Cs by 


\section{MInstitute ${ }_{\text {Mnk }}^{\text {Macrothink }}$}

American Council on the Teaching of Foreign Languages (ACTFL, 2006), aimed at preparing students to develop linguistic and intercultural competence (López-Rocha, 2016).

Multilingual classrooms can engender interlinguality (Lamb, 2015), which involves openness to flexible use of other languages in everyday life, as well as criticality, interculturality and multilingual entanglement (Williams \& Stroud, 2013) and which can challenge the "monolingual habitus" (Gogolin,2002) - set of assumptions built on the fundamental myth of uniformity of language and culture (Benson, 2013). In this context, English language teachers need "to understand the importance of representing the language knowledge of pupils in the classroom and to embrace this linguistic diversity as a learning resource for all classmates" (Calvo, 2017). The classroom needs to be moved from a monolingual to a plurilingual space. The bilingualism of pupils who speak a language other than that of the school can be a valuable resource for teaching and learning in a linguistic diversity classroom.

Here, I use the term multilingualism to refer to the presence of a range of languages in social spaces (e.g. the school), and plurilingualism to refer to an individual's capacity to use a range of languages.

Considering all these scenarios and issues, I want to explore how English language teachers deal with the issue of multilingual and plurilingual classes in their EMI language policy classrooms, as this can be a new area of interest of carrying out a research study in the context of Nepal. Due to multilingualism as a common phenomenon, no one can be purely monolingual in the modern globalized society. Despite this fact, schools still follow the monolingual policy in teaching learning activities in the classroom, with either Nepali or English medium of instruction, neglecting linguistic diversity. Therefore, my research in this area can be so fruitful to explore the issue of linguistic diversity in the English classroom with EMI policy. This study will be quite relevant for the concerned bodies like the English teachers, the school administrators, etc. to make the policy to address the issue of linguistic diversity in their school contexts. As far as I know, no study has been done in this particular field.

\section{Purpose of the Study}

The purpose of this study is to explore how the English language teachers address the issue of students' linguistic diversity in EMI language policy classrooms, whether they take this as a challenge of teaching or chance for learning for the learners.

\section{Research Questions}

This study aims at finding out the answers of these research questions:

1. How do English language teachers address the issue of students' linguistic diversity in their EMI classrooms? 
2. Do they take linguistic diversity as a challenge of teaching or chance for learning?

3. Why do they take linguistic diversity as a challenge or chance?

\section{Theoretical Framework}

Being English as an international language (McKay, 2012; Sharifian, 2009), English language teaching must enhance its geographical scope and include non-mainstream linguistic and cultural diversity in a multilingual school space. Nepal is a multilingual country with various ethnic and non-ethnic groups speaking 123 languages, some with many speakers and others with only a few. Linguistic diversity is quite unevenly distributed across populations and regions in the urban context of Nepal.

Linguistic landscape (Landry \& Bourhis, 1997) in a multilingual school space is the main theoretical construct that guided this exploratory study. The concept of linguistic landscape has been used in several different ways in the literature. Here the concept has been used in a more general sense for the presence and use of many languages in a larger geographic area (e.g. the Baltic area by Kreslins, 2003; as cited in Gorter, 2006, p.1 ). In this sense, linguistic landscape refers to "the social context in which more than one language is present" (Gorter, 2006, p.1) forming multilingualism. In its looser sense, the word linguistic landscape is synonymous with concepts such as diversity of languages or the linguistic situation in a certain territory or sociolinguistic context. The linguistic landscape of schools in Kathmandu city is quite diverse. In this scenario, the present study explores how the English teachers take such a situation in EMI schools and for this purpose linguistic landscape theory works as theoretical framework.

Bourdieu's (1986) notion of cultural capital along with the power in society is another theoretical lens to explain the problems learners of ethnic groups face in mainstream multilingual schools. Bourdieu's cultural capital includes all non-financial social assets such as languages, knowledge, skills, position, competencies, qualifications, etc., which enable holders to mobilise social authority. When a holder of cultural capital uses the power against dominated social agents, seeking thereby to alter their actions, this represents symbolic violence in Bourdieu's term. Symbolic violence is actually misrecognizing the dominated agents' habitus with some kind of criticism, bullying and discrimination. Linguistic bullying in the multilingual classroom can be a form of symbolic violence. Bourdieu sees power as culturally and symbolically created, and legitimised through an interplay of agency and social structure.

A number of other theories notably 'translanguiging' (the term first coined in Welsh by Cen Williams as trawsieithu in his 1994), 'linguistic imperialism' (Phillipson, 1992), 'monolingual bias' (Kachru, 1994; Grosjean, 2008; Cenoz, \& Gorter, 2011).), 'Linguistic Genocide' (Phillipson \& Skutnabb-Kangas, 1992; Skutnabb-Kangas, 2000), 'intercultural sensitivity' (Chen, 1997), 'intercultural awareness' (Baker, 2011) and 'intercultural competence' (Byram, 1997) also explain the issue of linguistic diversity in English classrooms with EMI language policy in a multilingual school space. 
"Translanguaging entails using one language to reinforce the other in order to increase understanding and in order to augment the pupil's ability in both languages" (Williams, 2002; cited in Lewis, Jones \& Baker, 2012). Translanguaging can be a powerful tool for learning in a multilingual classroom space. Learners' linguistic repertoire can be used as a strategy if they are not able to understand what the teacher has to deliver in the mainstream classroom instruction. Translanguaging pedagogy sees languages as a property of the community. Research studies (Creese \& Blackledge, 2010; Martínez, Hikida \& Durán, 2015).) tell us that translanguaging can be used to support English language learners in the multilingual classrooms as a pedagogical tool.

Linguistic imperialism, spreading in the form of English through its global language education, undermines the rights of other indigenous languages in multilingual school contexts. This results in linguistic genocide. Linguistic genocide is defined (UN Convention 1948, Article 3,1 ) as "Prohibition of the use of the language of the group in daily intercourse or in schools, or the printing and circulation of publications in the language of the group" (cited in Phillipson \& Skutnabb-Kangas, 1992). Linguistic genocide mostly happens in EMI schools with mainstream education system. This is what Skutnabb-Kangas also calls linguicism (linguistic discrimination). One of the major causes of linguicism is monolingual bias practised through mainstream school education system. EMI language policy in schools supports monolingual bias against multilingualism.

Intercultural sensitivity (Bennett, 1984) has become a strong demand for living harmoniously in today's culturally diverse society. "The development of a 'global village' strongly demands the ability of intercultural sensitivity between people for all of us to survive in the 21 st century" (Chen, 1997). Together with "intercultural awareness" (Baker, 2011) and "intercultural competence" (Byram, 1997), intercultural sensitivity is a vital element for successful communication in a global village (Barnlund, 1988).

Intercultural competence is the ability to communicate effectively and appropriately with people from different cultures. Drawing on fluid, dynamic notions of cultures and languages in intercultural communication, Baker (2011) defines intercultural awareness as follows:

Intercultural awareness is a conscious understanding of the role culturally based forms, practices and frames of reference can have in intercultural communication, and an ability to put these conceptions into practice in a flexible and context specific manner in real time communication (p.202).

The model of intercultural awareness consists of knowledge, skills, cultural awareness and intercultural awareness for intercultural communication in a multilingual social space. So the learners need to have knowledge, skills, attitudes and cultural awareness in the linguistically diverse classrooms for effective and appropriate communication with friends from other cultures. All this requires intercultural sensitivity to communicate successfully in the culturally diverse social space.

Overall, the present study aims to explore the situation of linguistically diverse space of 
school education where there is the practice of EMI though classrooms are multilingual. So I claim that this can be a totally new area of research in the context of Nepal's mainstream school education system. Though Nepal is a multilingual and multicultural country, public schools have the trend of implementing EMI policy neglecting the languages of minority ethnic groups in this globalised space. In view of this, it can be an interesting area of research beneficial for policy makers, administrators, educators and teachers concerned in the field.

\section{Methods}

\subsection{Research Design}

This study employs a phenomenological research design, which "describes the meaning for several individuals of their lived experiences of a concept or a phenomenon" (Creswell, 2007, p.57) with a focus "on the participants' perceptions of the event or situation" (Williams, 2007, p.69). This research study is qualitative in nature in that it attempts to explore information regarding the phenomenon of addressing the issue of linguistic diversity in the English classroom.

\subsection{Participants}

The participants of the study consisted of three English teachers, teaching English at secondary level in Kathmandu. Out of three English teachers, two were females (Mrs Lama and Mrs Lamichhane) and one was male ( $\mathrm{Mr} \mathrm{KC})$. These participants were selected inclusively in terms of ethnicity/caste and sex. Only the surnames are used for ethical consideration and to give the sense of ethnicity along with titles like Mrs for their sexual identity. Mrs Lama speaks Tamang while other two speak Nepali as their mother tongues. They were informed before, after and during the research process about the aims. The participants were affirmed to be volunteers in the study. The participants for this study were selected using purposive sampling technique.

\subsection{Tools}

The information collection instrument consisted of two parts, background interview and open-ended questions asked orally. The background interview interrogated the pre-service English language teachers about their name, experiences, and level of study. Open-ended interview mainly included research questions relevant to the study. The participants were asked to express their experiences and views regarding the issue of linguistic diversity in their English classrooms. To conclude, the research was conducted qualitatively as the semi-structured interview technique was used to gather information from the participants' point of view.

\subsection{Procedure}

The study was employed a two-step procedure: information collection and information analysis. In information collection, the participants were asked to express their experiences and views regarding the issue of dealing with linguistic diversity in the English classrooms. 
Their interview was audio-recorded taking their permission. After collecting relevant information, interviews were transcribed, coded, and analyzed and interpreted using a thematic approach, and discussed linking with relevant theories. Based on the discussion, conclusion was drawn recommending areas of exploration for further research.

\section{Results and Discussion}

On the basis of the information collected from three English language teachers, teaching at secondary level in public schools in Kathmandu, I have drawn some themes of the study. So this section presents the results of the qualitative data analysis about the issue of dealing with linguistic diversity in the English classrooms. The results of the qualitative analysis are reported and discussed in three themes: linguistic diversity as a learning resource, monolingual practice in multilingual classroom and linguistic diversity as a challenge.

\subsection{Linguistic Diversity as a Learning Resource}

Consideration of linguistic and cultural diversity in the English classroom can be a valuable learning resource for the learners as it helps to avoid language discrimination of pupils who have a different home language from that of the school. Recognizing the pupils' own linguistic and cultural knowledge as capital in the sense of Bourdieu can be a good strategy in order to understand and value their identity. Therefore, English language teachers have to discover the linguistic and cultural diversity existing in their school community and transform this diversity into knowledge for pupils.

All the participants in this study agree that linguistic and cultural diversity is a valuable resource for learning to the pupils. They do not agree that 'one-size-fits-all' technique works well in linguistically diverse classroom. In the English classroom, linguistic diversity is a good resource of knowledge. As Mrs Lama says I just make them that in which language you feel easy (.) you can speak out, and then .... I just allow them that if you want to share in your own language (..) then you can tell but you have to translate because I can't understand your language so you can translate into Nepali. From her expression, it is evident that she values the learners' mother tongue in the English class. Since she does not understand all the learners' mother tongue, she asks them to translate that into Nepali or even English. It means she is applying translanguaging strategy in her classroom. $\mathrm{Mr} \mathrm{KC}$ also makes use of translingual method as he says while delivering the contents...I use .....Nepali and very often I use English language.

In response to the question do you welcome the pupils' home language?, Mrs Lama replied, "Yes, of course, I allow them. I welcome them (.) and I tell them if you want to speak then you also speak and then let me know also". Mr KC also welcomes the use of learners' mother tongues as he says, "I welcome and I do realize also there should b e judicious use of mother tongue in the classroom". Similarly, Mrs Lamichhane replies that "they will start sharing their ideas .... in Tamang language or in Nepali language in my classroom”. All these 
expressions clarify that the participant teachers give value in the use of learners' mother tongues recognizing linguistic and cultural diversity. It is in fact justifiable and appropriate, as this kind of diversity is a valuable source for pupils in a multilingual English classroom. Recognizing the value of pupils' home language and culture can help reduce the gap between their home and school environment, thereby making them feel comfortable at school. Therefore, it can be fruitful to transform the monolingual classroom into a more open, multilingual and multicultural space from the learning point of view. The teacher is the person responsible for transmitting knowledge and skills to pupils within the institutional framework of the school.

Linguistic and cultural diversity is not only the resource for learning to the pupils but also for teachers. This is evident from the expression of Mrs Lamichhane when she says cultural and linguistic background is the opportunity for us to handle our classroom and to share our ideas (.) I am too learning from them. Teachers are also the learners in a sense. As Mrs Lamichhane says, linguistic and cultural diversity creates learning environment to the teachers to learn as well and she confesses that she is also learning due to that kind of classroom diversity.

Linguistic diversity can be a good source for developing intercultural awareness in the learners in the present day mixed societies. Raising intercultural sensitivity in the learners has become a striking issue for cooperative learning in multilingual and multicultural English classrooms. English classrooms are linguistically diverse and culturally rich in urban cities like Kathmandu. So, it has become inevitable to develop intercultural attitude, knowledge and skills in the learners for effective and appropriate intercultural communication. Linguistic diversity helps to build intercultural knowledge and skills in the learners to be fit in the multilingual societies. Mr KC says that linguistic diversity is a chance for learners to develop intercultural knowledge, competence and skills. Mrs Lama also confesses that linguistic diversity is source for knowledge but EMI is just being a barrier. Mrs Lamichhane also has the similar view arguing that linguistic diversity will build intercultural knowledge and skills developing positive attitudes towards each other's cultures. For effective intercultural communication, linguistic diversity works as a valuable learning space for the pupils if this kind of situation is wisely recognized by the teachers.

\subsection{Monolingual Practice in Multilingual Classrooms}

Monolingual practice has been a common phenomenon in multilingual classrooms in the context of Nepal. The schools I selected have English as a medium of instruction (EMI) policy though English classes are linguistically and culturally diverse. Learners are from various ethnic backgrounds such as the Tamangs, the Newars, etc. with their own languages, and some of them are from Brahmin and Chhetri families with Nepali as their first language. All the participants of this study have preference of multilingualism though they are teaching in EMI public schools in Kathmandu.

When I asked What do you think about EMI language policy in a multilingual classroom?, all the three participants responded that it is not justifiable to use EMI language policy in such contexts. Yet they are the English teachers of such schools with EMI policy. In the view of 
Mrs Lama, if students are not understanding (.) students are not getting that knowledge content subject matter (.) then that is using EMI is worthless, I think. She is in fact right to say so because knowledge is more important than medium of instruction; if learners are not understanding, then what's the use of EMI? It is a serious question that she raised. Though she is against EMI policy and prefers multilingual practice, she cannot do anything because her voice is suppressed. In this regard, she expresses: multilingualism is needed but what to do (.) we can't do anything else because single voice is suppressed here. Her view reflects Bourdieu's power theory, as she says our principal (.) our SMC members (.) most of them also they want EMI instruction. She is compelled to implement the EMI policy in her classroom and she is helpless in her voice against this monolingual policy. In EMI, English is working as a form of 'linguistic imperialism' (Phillipson, 1992 ).

$\mathrm{Mr} \mathrm{KC}$ also expresses his dissatisfaction about EMI policy in this way: since ... so many students are there .... even they can't understand Nepali language itself but Nepali language is our national language (..) so how can they understand English language?. However, Mrs Lamichhane is of the opinion that EMI will not suppress, rather it will support about the cultural diversity (.) linguistic diversity of the students, arguing that English is the necessity of the world. She further argues that most of the students are becoming a bit confident about using English and they are being able to compete with the boarding school students. What we can infer from her arguments is that public schools can attract students by EMI policy to down the institutional schools.

Anyway, EMI language policy creates 'monolingual bias' (Kachru, 1994; Grosjean, 2008) in multilingualism. This policy cannot address the issue of linguistic and cultural diversity prevalent in the urban areas in Nepal. Mrs Lama and Mr KC argue that English works as a killer language to other languages. To quote Mrs Lama:

English is the killer language of the other languages....even though 123 languages (.) all they are being just like a shadowed (.) shadowing part and then the English which one if from the other country and it is being a dominant and that one is controlling....English language is killing our languages (.) our own ethnic group identity is being just disappearing day by day.

This is in fact a serious issue, EMI functioning as a language killer policy. It is in fact what Skutnabb-Kangas (2000) called "Linguistic Genocide in Education". Schools are every day committing linguistic genocide (Skutnabb-Kangas, 2000). EMI is creating inequalities between English and other ethnic languages including Nepali as symbolized by linguistic imperialism (Phillipson, 1992), and the ultimate loss of minority languages described as language death (Crystal, 2000) or linguistic genocide (Nettle \& Romaine, 2000; Skutnabb-Kangas, 2000). Therefore, EMI policy seems to be against linguistic and cultural diversity in multilingual English classrooms in Nepal. Then should this policy be changed or should there be multilingual or translanguaging practice can be an issue for further investigation in the context of Nepal.

Mrs Lama confesses that EMI language policy is the main obstacle for teachers as well as for 
learners in multilingual classrooms. As she expresses:

whenever I just ask the students some questions related to the topic or the subject matter and then they want to share....first they ask that can I speak in Nepali? Then if we say that no you are not allowed ......you have to tell in English (.) then they say okay 'vaigyo'(I don't want to share) .... they say like this one.

What we can infer from this expression is that learners are eager to share their ideas about the subject matter, but due to English-only policy, they are inhibited from expressing their feelings, experiences and ideas. English-only policy is not a justice for learners with various language and socio-cultural backgrounds. But how to change linguistic diversity as an opportunity for leaning can be an issue for further investigation.

\subsection{Linguistic Diversity as a Challenge}

Linguistic diversity can be a challenge of teaching for those teachers who lack 'multilingual awareness' (Garcia, 2008). Learners come from various socio-cultural backgrounds in a multilingual school and they have their own experiences and knowledge. However, teachers may take them as challenging groups for effective teaching (if effective teaching is considered to occur in a silent class with the same language background of all the pupils) in English classrooms. In response to the question Don't you think linguistic diversity is a challenge for the English language teachers?, Mrs Lama replied that according to this EMI policy (.) this one is the challenge. As Mrs Lama says, EMI may not allow pupils' to use their own languages so that linguistic diversity cannot be used as a resource for learning to develop intercultural knowledge. She considers EMI language policy as a challenging factor for the English language teachers in a multilingual classroom. Similarly, Mr KC argues that since learners are from different language backgrounds, it is quite difficult regarding whose mother tongue be used in the multilingual classroom, and teachers may not know all the learners' mother tongues.

Another participant of this study, Mrs Lamichhane, confesses that she is facing the problem of linguistic diversity in her multilingual English classroom, where there is also EMI policy. However, she says challenge is there but we have to change that challenge into opportunity. When I asked her how to change linguistic diversity into an opportunity for learning, she replied by giving project work about different sorts of subject matters in which they can use their cultural matters sharing their ideas about them.

Linguistic bullying as symbolic violence is another problem of linguistic diversity in a multilingual classroom that teachers may encounter. When learners are from various ethnic and regional language backgrounds, they may speak with different accents and different tone. At that time, learners from the mainstream group may start bullying them with their nicknames and by copying their accents and styles. As Mrs Lama reveals, she finds linguistic bullying to the Newari and the Tamang language background pupils due to their own accents and tones in the mainstream classroom where most of the learners are from Nepali language backgrounds. To quote her: especially from the Tamang they mostly use a for most of the 
things and then other students start to tease them and then sometimes they start to give titles...they give that some nickname. Mrs Lamichhane had a similar experience of what Bourdieu calls symbolic violence. In her classroom at grade $10 \mathrm{~A}$, Mrs Lamichhane had a student from Madhesi language background. Due to his Madhesi accent and tone, other friends used to tease him and he used to feel hesitated and anxious about his tone. But later on, when she heard about that case, she convinced other students not to tease him, rather to help him, as he was also their own class friend. Then they stopped bullying and started helping him. As a result, he became very confident in learning and he did not have any sort of problem. So linguistic diversity due to different ethnic language backgrounds may create a problem in the English classroom. Actually linguistic bullying is quite bad to develop intercultural knowledge and create cooperative learning environment for the learners in the classroom. Since linguistic landscape in the classroom cannot be changed, friendly environment can be created for effective and fruitful learning, and the linguistic diversity as a challenge can be changed into an opportunity for learning through intercultural awareness.

\section{Conclusion}

Linguistic diversity can be a challenge of teaching as well as a chance for learning in a multilingual classroom in urban areas. Since linguistic diversity has been a common linguistic landscape in multilingual social contexts like Kathmandu, it has become a challenge of teaching for English language teachers as well as chance for learning to the pupils in culturally diverse societies. Linguistic diversity is a challenge of teaching for the teachers because learners come from various language and cultural backgrounds and they have to learn English, which is different from their home or native language. It is a chance for learning in the sense that learners have to live in culturally rich and linguistically diverse societies in the urban contexts. As we cannot change the linguistic landscape of our mixed society, it can be wiser if we change linguistic and cultural diversity into an opportunity for learning through intercultural awareness. In fact, linguistic diversity in the English classroom can be a valuable resource for learning to develop intercultural communicative competence in the learners to cope with culturally diverse social contexts. Exploring teacher's identity in a linguistically diverse English classroom can be an issue for further investigation.

\section{References}

ACTFL. (2006). Standards for foreign language learning in the 21st century (3rd ed.). Yonkers, NY: National Standards in Foreign Language Education Project.

Baker, W. (2011). Intercultural awareness: Modelling an understanding of cultures in intercultural communication through English as a lingua franca. Language and Intercultural Communication, 11(3), 197-214. https:/doi.org/10.1080/14708477.2011.577779

Barnlund, D. C. (1988). Communication in a global village. In L. A. Samovar, \& R.E. Porter (Eds.), Intercultural communication: A reader. CA: Wadsworth. 
Bennett, M. J. (1984). Towards ethnorelativism: A developmental model of intercultural sensitivity. Paper presented at the Annual Conference of the Council on International Exchange, Minneapolis, Minnesota.

Benson, C. (2013). Towards adopting a multilingual habitus in educational development. In C. Benson \& K. Kosonen (Eds.), Language Issues in Comparative Education. Rotterdam: SensePublishers.

Bista, K. (2011). Teaching English as a Foreign/Second Language in Nepal: Past and present, 11(32). Retrieved from https://files.eric.ed.gov/fulltext/ED530898.pdf

Bourdieu, P. (1986). The forms of capital. In J. Richardson (Ed.), Handbook of theory and research for the sociology of education (pp. 241-258). New York: Greenwood.

Byram, M. (1997). Teaching and assessing intercultural communicative competence. Clevendon: Multilingual Matters.

Byram, M. (1997). Teaching and assessing intercultural communicative competence. Clevedon: Multilingual Matters.

Calvo, X. P. (2017). Dealing with linguistic diversity in the classroom: a challenge for teachers. $\quad$ Retrieved from http://euliteracy.eu/wp-content/uploads/2017/07/Dealing-with-linguistic-diversity-in-the-class room-a-challenge-for-teachers.pdf

Cenoz, J., \& Gorter, D. (2011). A holistic approach to multilingual education: Introduction. The Modern Language Journal,95(3), 339-343. https://doi.org/10.1111/j.1540-4781.2011.01204.x

Chen, G. (1997). A review of the concept of intercultural sensitivity. Paper presented at the Biennial Convention of the Pacific and Asian Communication Association (Honolulu, HI).

Creese, A., \& Blackledge, A. (2010). Translanguaging in the bilingual classroom: A pedagogy for learning and teaching? The Modern Language Journal, 94(1), 103-115. https://doi.org/10.1111/j.1540-4781.2009.00986.x

Crystal, D. (2000). Language Death. Cambridge: Cambridge University Press.

Garcia, O. (2008). Multilingual language awareness and teacher education. In Encyclopedia of language and education (pp. 2130-2145). Springer, Boston, MA.

Gogolin, I. (2002). Linguistic and cultural diversity in Europe: A challenge for educational research and practice. European Educational Research Journal, 1(1), 123-138. https://doi.org/10.2304/eerj.2002.1.1.3

Gogolin, I., \& Duarte, J. (2017). Superdiversity, multilingualism, and awareness. In Cenoz J., Gorter D., \& May S. (Eds.), Language Awareness and Multilingualism, Encyclopedia of Language and Education (3rd ed.). Switzerland: Springer.

Gorter, D. (2006). Introduction: The study of the linguistic landscape as a new approach to 
multilingualism. In D. Gorter (Ed.), Linguistic landscape: A new approach to multilingualism (pp. 1-6). Clevedon: Multilingual Matters.

Grosjean, F. (2008). Studying bilinguals. Oxford: Oxford University Press.

Hennebry, M. (2014). Cultural awareness: should it be taught? Can it be taught? In P. Driscoll, E. Macaro, \& A. Swerbrick (Eds.), Debates in modern languages education. London: Routledge.

Kachru, Y. (1994). Monolingual bias in SLA research. TESOL Quarterly, 28(4), 795-800.

Lamb, T. (2015). Towards a plurilingual habitus: Engendering interlinguality in urban spaces. International Journal of Pedagogies and Learning, 10(2), 151-165. https://doi.org/10.1080/22040552.2015.1113848

Landry, R., \& Bourhis, R. Y. (1997). Linguistic landscape and ethnolinguistic vitality: An empirical study. Journal of language and social psychology, 16(1), 23-49. https://doi.org/10.1177/0261927X970161002

Lear, D. W., \& Abbott, A. R. (2008). Foreign language professional standards and CSL: Achieving the 5 C's. Retrieved from https://files.eric.ed.gov/fulltext/EJ831378.pdf

Lewis, G., Jones, B., \& Baker, C. (2012). Translanguaging: Origins and development from school to street and beyond. Educational Research and Evaluation, 18(7), 641-654. https:/doi.org/10.1080/13803611.2012.718488

López-Rocha, S. (2016). Intercultural communicative competence: creating awareness and promoting skills in the language classroom. In C. Goria, O. Speicher, \& S. Stollhans (Eds.), Innovative language teaching and learning at university: enhancing participation and collaboration (pp. 105-111). Dublin: Research-publishing.

Martínez, R. A., Hikida, M., \& Durán, L. (2015). Unpacking ideologies of linguistic purism: How dual language teachers make sense of everyday translanguaging. International Multilingual Research Journal, 9(1), 26-42. https://doi.org/10.1080/19313152.2014.977712

McKay, S. L. (2002). Teaching English as an international language: Rethinking goals and approaches. Oxford: Oxford University Press.

McKay, S. L. (2012). English as an international language. In Jack C. Richards \& Anne Burns (Eds.), The Cambridge guide to pedagogy and practice in second language teaching (pp. 15-22). New York NY: Cambridge University Press.

Moeller, A. K., \& Nugent, K. (2014). Building intercultural competence in the language classroom.

Retrieved

from http://digitalcommons.unl.edu/cgi/viewcontent.cgi?article=1160\&context=teachlearnfacpub

National Population and Housing Census 2011. Kathmandu: Government of Nepal, National Planning Commission Secretariat, Central Bureau of Statistics.

Phillipson, R., \& Skutnabb-Kangas, T. (1994). Linguistic Genocide. In Valodas politika 


\section{Macrothink}

Baltijas Valstīs, Language Policy in the Baltic States. Rīga: Krājumu sagatavojis. Latvijas Republikas Valsts valodas centrs, 140-150.

Phillipson, R. (1992). Linguistic imperialism. Oxford: Oxford University Press.

Phillipson, R., \& Skutnabb-Kangas, T. (1992). Linguistic genocide. Paper at the Conference language Policy in the Baltic States, Riga, December 17-18. Retrieved from https://www.academia.edu/32244769/LINGUISTIC_GENOCIDE

Sharifian, F. (Ed.) (2009). English as an international language: Perspectives and pedagogical issues. Bristol: Multilingual Matters.

Shrestha, P. (2008). ELT, ESP \& EAP in Nepal: Whose interests are served? In M. Krzanowski (Ed.), EAP and ESP in Developing Countries: State of Play vs Actual Needs and Wants. Canterbury: IATEFL (ESP SIG), pp. 191-210.

Shrestha, R. (1983). English as a second language/English as a foreign language distinction: Its pedagogy and the Nepalese context. Contributions to Nepalese Studies, 11(1), 45-59.

Skutnabb-Kangas, T. (2000). Linguistic genocide in education - Or worldwide diversity and human rights?. Mahwah, NJ: Lawrence Erlbaum Associates, Inc., Publishers.

Williams, Q. E., \& Stroud, C. (2013). Multilingualism in transformative spaces: contact and conviviality. Language Policy, 12(4), 289-311. https://doi.org/10.1007/s10993-012-9265-4

\section{Biography}

Mohan Singh Saud is currently a $\mathrm{PhD}$ candidate at Graduate School of Education, Tribhuvan University, Nepal. He has been teaching English at Kailali Multiple Campus, Dhangadhi, Nepal since 2004. He has published some books including school level English series, some journal articles. His areas of interest include grammar teaching, professional development, English medium instruction (EMI), mother tongue-based medium of instruction, teaching English as an international language, English language teachers' training and education, linguistic diversity and globalization.

\section{Copyright Disclaimer}

Copyright for this article is retained by the author(s), with first publication rights granted to the journal.

This is an open-access article distributed under the terms and conditions of the Creative Commons Attribution license (http://creativecommons.org/licenses/by/3.0/). 